\title{
Słowo wprowadzające
}

doi https://doi.org/10.15633/9788374389839.00

Monografia wieloautorska pt. Teoretyczno-empiryczne interpretacje tożsamości społecznej z uwzględnieniem perspektywy familiologii jest zbiorem artykułów prezentujących zróżnicowane podejścia do problematyki „tożsamości społecznej”, analizowanej zarówno jako konstrukt teoretyczny, jak i obiektywny fakt społeczny. „Tożsamość społeczna” to pojęcie najlepiej opisane i zbadane dotychczas na gruncie socjologii, dlatego prezentowana monografia ma charakter w przeważającej mierze socjologiczny. Oczywisty jest jednak fakt, że jej zrozumienie i interpretacja, bez psychologii, filozofii, pedagogiki, antropologii i wielu innych dziedzin - traktowanych w tym wypadku jako nauki pomocnicze - są niemożliwe, stąd szczególnie istotna była współpraca zróżnicowanego wewnętrznie grona autorów.

Publikacja ta, jak już wspomniano, jest owocem współpracy naukowców i doktorantów z Uniwersytetu Papieskiego Jana Pawła II w Krakowie oraz Akademii Ignatianum. Wspólnym punktem wyjścia do przygotowania zgromadzonych tu artykułów była refleksja nad mnogością i zmiennością teoretycznych opisów tożsamości społecznej, a także rozległe możliwości zastosowania tego pojęcia do opisu zróżnicowanych sytuacji związanych ze światem relacji międzyludzkich. Bogactwo tego świata powoduje, że - mimo wielu publikacji na temat tożsamości społecznej - ciągle jest miejsce na kolejne interpretacje i próby aplikacji teorii do codziennego życia, próby czynione z nadzieją, że okażą się przydatne poznawczo i pożyteczne dla Czytelników tej monografii.

Nieustannie otwarte pozostają poniższe pytania: Jak konstruować własną tożsamość? W jaki sposób radzić sobie z intensywnymi zmianami społecznymi? Jak wspierać innych i czerpać satysfakcję $\mathrm{z}$ bycia $\mathrm{z}$ innymi? Ja- 
kimi kierować się zasadami w codziennych działaniach? Jakie wartości mają znaczący wpływ w procesie kształtowania tożsamości społecznej? Są to pytania dotyczące tego, jak żyć, aby mimo braku map i drogowskazów w racjonalny i godny sposób przeżyć czas, jaki mamy do wykorzystania. Nad odpowiedziami na te pytania każdy człowiek zastanawia się częściej lub rzadziej, ale pojawiają się one nieuchronnie i stają się coraz bardziej znaczące.

Należy mieć nadzieję, że zamieszczone w pracy studia i rozważania pomogą Czytelnikom mniej zajmującym się tą problematyką poznać ją i zrozumieć, a Ci, którzy z racji swych zainteresowań naukowych i prowadzanych badań są już z nią w dużej mierze zaznajomieni, znajdą w książce nowe ujęcia i dodatkowe analizy.

Zapraszając Czytelników do lektury tego interesującego opracowania, serdecznie dziękujemy wszystkim osobom, które miały wkład w przygotowanie niniejszej publikacji, szczególnie Redakcji. Jesteśmy wdzięczni ks. prof. dr. Michałowi Drożdżowi, dziekanowi Wydziału Nauk Społecznych, za życzliwe wsparcie tego wydania. 